\title{
The adaptation of coral reefs to climate change: Is the Red Queen being outpaced?
}

\author{
OVE HOEGH-GULDBERG
}

Global Change Institute, University of Queensland, Saint Lucia 4072 QLD, Australia. E-mail: oveh@uq.edu.au

\begin{abstract}
SUMMARY: Coral reefs have enormous value in terms of biodiversity and the ecosystem goods and services that they provide to hundreds of millions of people around the world. These important ecosystems are facing rapidly increasing pressure from climate change, particularly ocean warming and acidification. A centrally important question is whether reefbuilding corals and the ecosystems they build will be able to acclimate, adapt, or migrate in response to rapid anthropogenic climate change. This issue is explored in the context of the current environmental change, which is largely unprecedented in rate and scale and which are exceeding the capacity of coral reef ecosystems to maintain their contribution to human wellbeing through evolutionary and ecological processes. On the balance of evidence, the 'Red Queen' (an analogy previously used by evolutionary biologists) is clearly being 'left in the dust' with evolutionary processes that are largely unable to maintain the status quo of coral reef ecosystems under the current high rates of anthropogenic climate change.
\end{abstract}

Keywords: climate change, coral reefs, heat stress, warming, ocean acidification, adaptation, community change, migration, Red Queen.

RESUMEN: LA ADAPTACIÓN DE LOS ARRECIFES DE CORAL AL CAMBIO CLIMÁTICO: ¿ESTÁ SIENDO SUPERADA LA REINA RoJA? - Los arrecifes de coral poseen un enorme valor en términos de biodiversidad y de los servicios ecosistémicos que proporcionan a cientos de millones de personas en todo el mundo. Estos importantes ecosistemas se enfrentan a una presión cada vez mayor por parte del cambio climático, en particular del calentamiento y la acidificación de los océanos. Una pregunta de gran trascendencia es si los corales arrecifales y los ecosistemas que ellos albergan serán capaces de aclimatarse, adaptarse o migrar, en respuesta al rápido cambio climático antropogénico. Este tema se analiza en el contexto del cambio medioambiental actual, en gran medida sin precedentes en su rapidez y alcance y que está superando la capacidad de los ecosistemas de los de arrecifes de coral para preservar su contribución al bienestar humano a través de procesos evolutivos y ecológicos. En base a las evidencias existentes, la 'Reina Roja' (una analogía utilizada en biología evolutiva) se está quedando atrás, "mordiendo el polvo", a través de unos procesos evolutivos que son incapaces de mantener el statu quo de los ecosistemas de los arrecifes de coral ante la actual rapidez del cambio climático antropogénico.

Palabras clave: cambio climático, arrecifes de coral, estrés térmico, calentamiento, acidificación oceánica, adaptación, cambio de la comunidad, migración, Reina Roja.

Coral reefs are complex ecosystems that are comparable to rainforests in their biological diversity and complexity (Reaka-Kudla 1997). In addition to their biodiversity, coral reefs also generate ecosystem goods and services that include food, building materials, coastal protection, as well as tourist and fisheries income to hundreds of millions of people, many of whom belong to impoverished communities that line tropical coastlines (Moberg and Folke 1999). Coral reefs are also threatened by a series of local and global stressors (Bryant et al. 1998, Hoegh-Guldberg et al. 2007, Halpern et al. 2008), which have caused the steady decline of dominant coral communities across large parts of the world (the IndoPacific, Bruno and Selig 2007, Hughes et al. 2011) and the almost complete collapse in other regions (e.g. the Caribbean, Hughes 1994; the Arabian Gulf, Riegl 2003). While local factors such as overfishing and deteriorating water quality have played significant roles in this decline 
in the past, climate change is widely perceived as the dominant threat, especially over the coming decades and century (Hoegh-Guldberg 1999, West and Salm 2003, Hughes et al. 2007, Hoegh-Guldberg et al. 2011).

There is growing evidence of serious impacts to coral reef ecosystems from a rapidly changing global environment (Baker et al. 2008). The word 'rapidly' is used in the context of the otherwise high degree of stability that global environments have mostly experienced over the past several thousand years (HoeghGuldberg et al. 2007). Comparing the current temperature and carbonate chemistry of coral reef waters, coral reefs are headed for combined temperatures and ocean chemistries that have no precedents in millions of years (Hoegh-Guldberg et al. 2007, Pelejero et al. 2010). Projections of how conditions will change in tropical oceans in the future suggest that the lower end of global climate scenarios $\left(450 \mathrm{ppm}\right.$ and $2^{\circ} \mathrm{C}$ above the preindustrial global temperatures) will be enough to push the majority of tropical reefs into a non-coraldominated state by as early as 2050 (Hoegh-Guldberg 1999, Done et al. 2003, Donner et al. 2005, HoeghGuldberg et al. 2007, Donner 2009). While there has been some speculation over whether some coral species may survive (Baker 2001, Berkelmans and Van Oppen 2006, Oliver and Palumbi 2009) and even evolve (Maynard et al. 2008), it is difficult to conclude that coral reefs (and their crucial ecological goods and services) will remain unchanged. What is often underemphasized in these arguments is that the survival of coral species is a necessary but not sufficient condition for the ongoing survival of coral reefs and their ecosystem goods and services: Corals as rare members of ecological assemblages do not equate to the complex coral reefs that are so crucial to humanity today.

How reefs will change over the coming decades and century will depend ultimately on whether the rate of environmental change is less than the rate at which corals and coral reef ecosystems can modify their physiological and ecological characteristics to accommodate these changes. In this respect, coral reef ecosystems might respond in two ways. First, they might evolve an increased tolerance to the many changes going on around them, or communities of species may become more tolerant as more sensitive species are weeded out. Second, species and ecosystems may redistribute themselves geographically. It has been suggested that both of these options reduce the challenge of climate change for coral reefs (Pandolfi et al. 2011), yet observations of these processes happening at sufficient speed, such that corals and coral reef ecosystems are able to maintain their presence and ecological services, are largely absent from the literature (Hoegh-Guldberg et al. 2007, HoeghGuldberg 2009). In contrast, a large number of studies show that coral communities are in rapid decline (e.g. Gardner et al. 2003, Bruno and Selig 2007) as a result of increasing local and global anthropogenic stresses within tropical coastal environments.

\section{Adaptation: Can the Red Queen keep up with climate change?}

Populations of any organism will respond evolutionarily if selective pressures such as those associated with climate change increase. More tolerant genotypes will be favoured over those that are less tolerant, leading to micro-evolutionary change as the relative proportion of different genotypes is modified by selection. Maintaining the abundance of a species within an ecosystem will ultimately depend on the amount of variability within a population or species range and how quickly the environment is changing. This leads to a 'race' between the ability of populations to modify genetically and the rate of environmental change. This is directly analogous to the Red Queen's dilemma (Van Valen 1973). In the words of the Red Queen: "It takes all the running you can do, to keep in the same place" (Carroll 1871).

Coral populations exhibit variability in tolerance to thermal stress within and between coral species (Hoegh-Guldberg and Salvat 1995, Loya et al. 2001, Coles and Brown 2003). These differences in tolerance can occur within a single site (Oliver and Palumbi 2009) or across geographic regions (Coles et al. 1976, Hoegh-Guldberg 1999) and are evidence that the evolution of stress tolerance has occurred in the past. At shorter time scales, the selective pressure associated with climate change is likely to drive micro-evolutionary changes within species and at the reef community level. Consequently, it is not inconceivable that some degree of adaptation may occur in short time scales (e.g. decadal) if organisms have short generation times (see Table 1 in Stockwell et al. 2003). However, few studies have been able to unambiguously demonstrate these types of evolutionary change for reef-building corals, probably because of their long generation times ( 3 to $\geq 100$ years, Hoegh-Guldberg 2009). For example, Maynard et al. (2008) claim to show a change in the sensitivity of reef-building corals at sites on the Great Barrier Reef between the two major bleaching events that occurred in 1998 and 2002. However, the results of the study remains ambiguous given that (a) it is not possible to conclude that the two bleaching events involved exactly the same amount of environment stress (e.g. light was not measured but is an important co-driver of mass coral bleaching), and (b) the study lacked the genetic precision required given that corals were only identified to genera (i.e. Acropora and Pocillopora). Consequently, the putative changes in sensitivity could easily have been due to shifts in the relative abundance of different species as opposed to evolutionary change within each species (Hoegh-Guldberg 2009). Similar problems were acknowledged in previous attempts to compare the overall sensitivity of corals between bleaching events in the eastern Pacific (Podestá and Glynn 2001).

Evidence of differences in thermal tolerance between genera and shifts in community composition of corals in response to stresses such as rising sea tem- 
peratures are more abundant (Hoegh-Guldberg and Salvat 1995, Marshall and Baird 2000, McClanahan et al. 2000, Loya et al. 2001, Obura 2001, McClanahan et al. 2002, Riegl 2002, Riegl 2003, McClanahan et al. 2007, McGehee 2008, Carpenter et al. 2008, McClanahan et al. 2009), with broad differences in thermal tolerance between genera such as Acropora and Pocillopora (relatively sensitive) and Porites and $\mathrm{Fa}$ via (less sensitive by $1-2^{\circ} \mathrm{C}$ ). Recent studies that have highlighted the flexibility of community composition along latitudinal gradients such as those found down the Great Barrier Reef further emphasize that changes in community composition are a likely outcome of early phases of global climate change (Bellwood and Hughes 2001, Hughes et al. 2012). Unfortunately, the additional tolerance of the majority of coral genera within specific ecologically isolated populations fall short of the forecasts of average sea temperature (and associated extremes), which are likely to increase by $1.8^{\circ} \mathrm{C}$ to $4^{\circ} \mathrm{C}$ (IPCC 2007) at the end of this century. How fast environmental changes occur is also important here in terms of how these community processes play out, throwing doubt on conclusions drawn as regards the ability of coral populations to keep up with rapid anthropogenic climate change. Given the pace of climate change, it is also unlikely that mutations or gene flow from other regions will be able to enter populations at rates that are fast enough to provide the novel genes required to build more thermally tolerant populations. Major problems also exist with the idea that thermal tolerance depends solely on the genetics of the endosymbiont, as has been popular in the literature (Buddemeier and Fautin 1993, Baker et al. 2004, Baker et al. 2008). The 'switching' of endosymbionts leading to increased thermal tolerance of corals has also not been observed (Hoegh-Guldberg 2009). In this regard, endosymbiont genotype is also a poor predictor of thermal tolerance, tending to vary almost entirely with the phylogeny of the host corals (LaJeunesse 2001, Stat et al. 2006). In addition to this, the thermal tolerance of the coral host appears to be as important as that of the symbionts (Dove 2004, Ainsworth et al. 2008). The sole focus on the genetics of the endosymbiont fails to recognize the highly integrated and co-evolved nature of coral hosts and their symbionts. This ultimately explains the absence of significant observations beyond speculative models (Baskett 2009) that clearly show corals 'switching' their endosymbionts and becoming more tolerant to rising sea temperatures.

Similar tolerance patterns hold for ocean acidification, with similar shifts in favour of genera such as Porites on coral reefs exposed to high $\mathrm{CO}_{2}$ (Fabricius et al. 2011). Ocean acidification, like temperature, is also influenced by the synergies and antagonisms that may arise between changes in temperature and acidity (Anthony et al. 2008) and local factors such as pollution and overfishing (Hughes et al. 2007). Most evidence suggests that reef-building corals are not maintaining their populations against the current rate of environ- mental change but instead are decreasing in abundance across entire regions and oceans (Hughes 1994, Gardner et al. 2003, Bruno and Selig 2007, Hughes et al. 2011, Sweatman et al. 2011). While these changes cannot be attributed solely to the rapid changes in ocean temperature and acidity, the observation that they are occurring in disturbed as well as putatively remote and pristine environmental settings (e.g. the Great Barrier Reef, De'ath et al. 2009) suggests that global stressors are playing a highly significant role in the global decline of reef-building corals. On the basis of this evidence, however, it would appear that the ecosystem equivalent of the Red Queen is being outpaced by environmental change that is several orders of magnitude faster than an ice age transition and resembles few if any changes in the recent geological record (HoeghGuldberg et al. 2007).

\section{Range shifts for ecosystems: What would it take to move the Great Barrier Reef?}

If the Red Queen is unable to keep pace with climate change at the one location, then maybe the strategy should be to relocate. Range shifts have been reported in a large number of terrestrial organisms, including birds and butterflies, which are now up to $200 \mathrm{~km}$ closer to the South and North Poles than they were 50 years ago (Parmesan et al. 1999, Parmesan and Yohe 2003). Similar observations have been made for marine organisms ranging from copepods to sea birds, with an average velocity of around 30-50 km per decade (E. Poloczanska, CSIRO, personal communication), matching the velocity (in some cases) at which isotherms are moving poleward (Burrows et al. 2011). The distribution of some reef-building corals show similar rapid shifts (up to $14 \mathrm{~km}$ per year, Precht and Aronson 2004, Yamano et al. 2011), which have also been recognized in past periods of time albeit with slower rates of change (e.g. Precht and Aronson 2004, Greenstein and Pandolfi 2008). These observations have prompted the suggestion that coral reefs might shift to higher latitudes, possibly counterbalancing the loss of coral reefs at lower latitudes and providing a reason for reduced concern about the sustainability of coral reefs in the future. However, the key question is whether this will occur at a rate sufficient for the ecosystem goods and services of coral reefs to remain intact.

There are several reasons why the forecasts of relocation are overly optimistic. The first is that warmer sea temperatures are not the only factor determining the distribution of coral reefs (Kleypas et al. 1999a, Kleypas et al. 1999b). As atmospheric $\mathrm{CO}_{2}$ increases, ocean $\mathrm{pH}$ and carbonate ion concentrations decrease, increasingly restricting suitable seawater chemistries for carbonate coral reefs to lower latitude sites (HoeghGuldberg et al. 2007). That is, changes in water chemistry from ocean acidification counter the advantages of ocean warming at higher latitudes. In addition, coral reef ecosystems require substantial light levels, which 


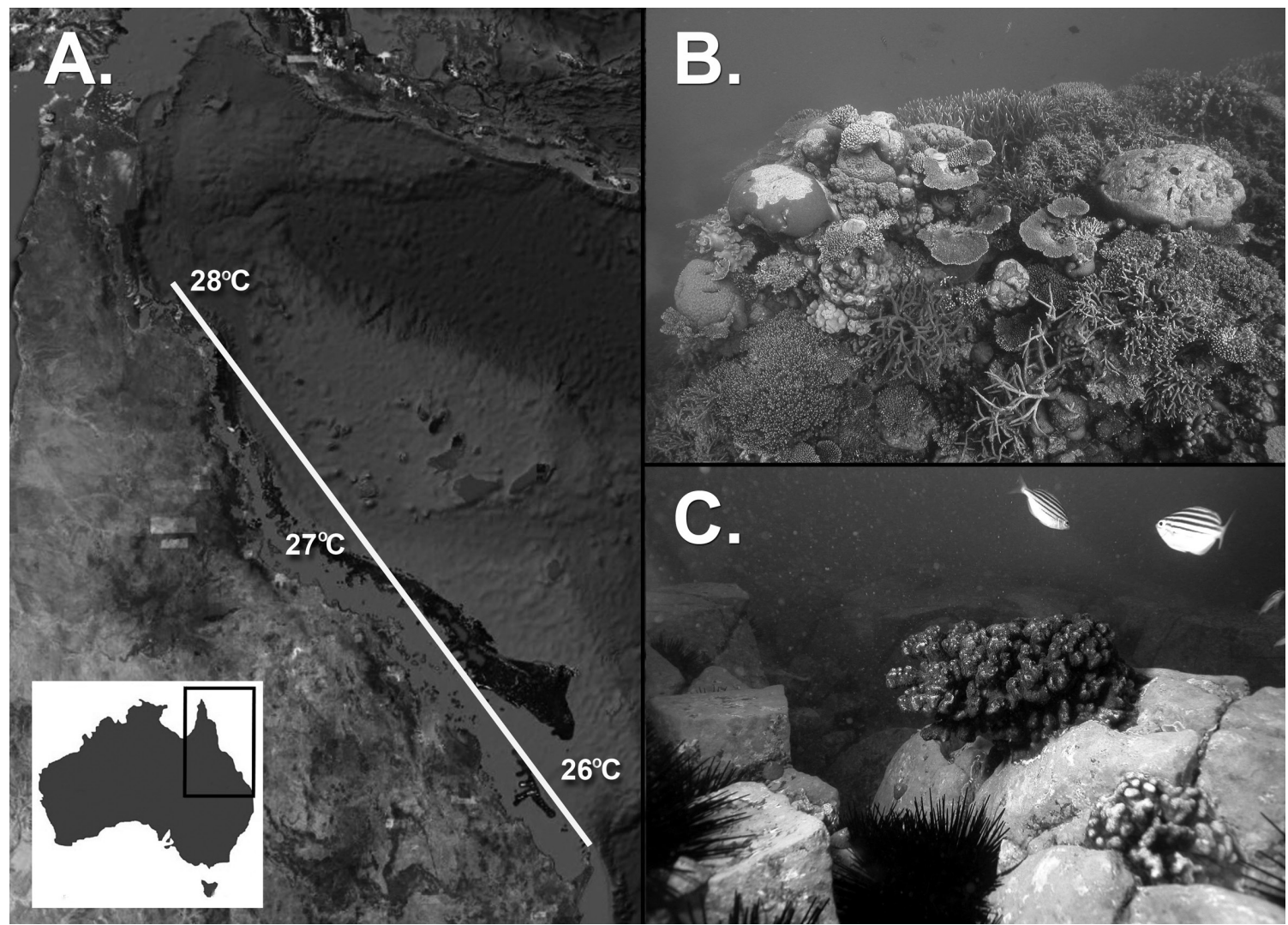

FIG. 1. - How fast would coral reef ecosystems have to travel if they were to keep up with the rapid shifts in sea temperature expected from climate change? A. Sea temperatures average $28^{\circ} \mathrm{C}$ in the northern Great Barrier Reef but decrease to an average of $26^{\circ} \mathrm{C}$ at the southern end (Done et al. 2003). Given that reef-building corals are locally adapted to temperature, the distance that would have to be travelled to keep pace with the $2{ }^{\circ} \mathrm{C}$ increase in sea temperature by year 2100 would be $1500 \mathrm{~km}$ (white line). For a $2^{\circ} \mathrm{C}$ increase in temperature from climate change over 100 years, this would mean that coral reef ecosystems would have to travel $15 \mathrm{~km}$ per year $(1500 \mathrm{~km} / 100$ years $)$. B. The translocation of complex ecosystems such as the coral reef shown (Agincourt Reef, off Port Douglas, northern Australia) has not been seen over such short timeframes. C. Individual coral species (here, Pocillopora damicornis growing at the high-latitude site of Fingal Bay in temperate New South Wales) are already migrating to higher latitudes but the chance of forming complex carbonate coral reefs in a few decades appears to be near to zero. Photos: O. Hoegh-Guldberg.

decrease at successively higher latitudes. The second reason is that the movement of coral species does not equate to the movement of coral reefs with their goods and ecological services intact (Fig. 1). This is often glossed over (Pandolfi et al. 2011, Yamano et al. 2011) but is centrally important for understanding the impacts of current global changes on coral reefs and the many people that depend on them. The observed migration of some species is interesting scientifically but falls far short of proving that an ecosystem as complicated as a coral reef is likely to shift in an intact state as the climate changes. The third reason is the extremely rapid speed at which coral reef ecosystems would have to shift if they were to keep up with the changing climate.

A simple set of calculations based on the Great Barrier Reef illustrates the mismatch between the rate at which the climate is changing and the ability of coral reefs to move. The Great Barrier Reef stretches 2100 $\mathrm{km}$ down the east coast of Australia, with average sea temperatures decreasing by approximately $2^{\circ} \mathrm{C}$ over the $1500 \mathrm{~km}$ segment shown in Figure 1A (Done et al. 2003). Corals are locally adapted to temperature, with those in the north being $2^{\circ} \mathrm{C}$ more tolerant on av- erage than those in south. This sets up the interesting calculation that reveals that coral reefs at the northern end of the Great Barrier Reef would have to travel at least $1500 \mathrm{~km}$ over the next 100 years to track changes in temperature at even the lower end of the IPCC scenarios $\left(+2^{\circ} \mathrm{C}\right.$, Fig. 1A). In terms of the speed of movement, this would mean that the entire set of species and ecological processes associated with the Great Barrier Reef have to migrate $15 \mathrm{~km}$ per year in order to keep pace with climate change. This throws doubt on the conclusions of Hughes et al. (2012) that the dynamic nature of coral communities should somehow allay our concerns about climate change. Relatively rapid events such as those leading up to the Holocene thermal maximum (Greenstein and Pandolfi 2008), when coral reefs expanded poleward by several hundred kilometres, occurred at much lower rates of change (probably no more than a few kilometres per century). An additional problem with the conclusion that coral reefs will move to higher latitudes is the fact that current atmospheric greenhouse gas concentrations are increasing. This means that selective pressure continuously increases over time, thereby making the establishment of reefs 
at any particular latitude problematic until sea temperatures stabilize. In this regard, the stabilization of conditions is an absolute requirement for the re-establishment of reef ecosystems and their goods and services at any new location. Under the current greenhouse gas scenario, this is unlikely for many hundreds if not thousands of years.

\section{CONCLUSION}

Coral reefs have been a persistent feature of tropical marine environments for several hundred million years. During this time, environments have changed in response to both local and global influences. Reefbuilding corals and the complex ecosystems that they build have responded to these challenges through evolutionary adaptation, changes to community structure, and the migration of species and ecosystems. The relatively slow rate of environmental change over most of this time (e.g. the past 420,000 years, $0.01 \pm 0.017^{\circ} \mathrm{C}$ per century, 99\% confidence interval, Hoegh-Guldberg et al. 2007) is a key characteristic of why these responses were possible without any apparent loss of coral reef abundance. In contrast, however, the rates of environmental change over the past 140 years (when the average global temperature has risen by $0.7^{\circ} \mathrm{C}$ per century) were much higher. Rates of change are even higher under even mild (IPCC B1, $1.8^{\circ} \mathrm{C}$ per century) and business-as-usual (IPCC A2, $3.1^{\circ} \mathrm{C}$ per century) greenhouse gas scenarios. The balance of evidence strongly suggests that organisms and ecosystems will continue to be outstripped in their ability to keep up with a rapidly changing climate which continues to drive their loss in terms of abundance and ability to provide ecosystem services. This 'Red Queen conundrum' further emphasizes why the rapid contraction of coral reefs is occurring across the planet, even in remote and pristine areas. Consequently, whether because of local or global factors, the ability of corals to adapt and absorb environmental change has been and will continue to be exceeded by the extraordinarily rapid rate at which human activities are modifying planetary conditions. This leads inevitably to the conclusion that unless we stabilize global conditions and dramatically modify and increase our conservation efforts (Rau et $a l$. in press), critically important ecosystems such as coral reefs will largely disappear by the middle to late part of this century.

\section{ACKNOWLEDGEMENTS}

Support for the preparation of this article was provided by the Queensland Smart State Premier's Fellowship and the Great Barrier Reef Foundation.

\section{REFERENCES}

Ainsworth T.D., Hoegh-Guldberg O., Heron S.F., Skirving W.J., Leggat W. 2008. Early cellular changes are indicators of prebleaching thermal stress in the coral host. J. Exp. Mar. Biol.
Ecol. 364: 63-71.

Anthony K.R., Kline D.I., Diaz-Pulido G., Dove S., Hoegh-Guldberg O. 2008. Ocean acidification causes bleaching and productivity loss in coral reef builders. PNAS 105: 17442-17446.

Baker A.C. 2001. Reef corals bleach to survive change. Nature 411: 765-766.

Baker A.C., Starger C.J., McClanahan T.R., Glynn P.W. 2004. Corals' adaptive response to climate change. Nature 430: 741-741.

Baker A.C., Glynn P.W., Riegl B. 2008. Climate change and coral reef bleaching: An ecological assessment of long-term impacts, recovery trends and future outlook. Est. Coast. Shelf Sci. 80: 435-471.

Baskett M. 2009. Symbiont diversity may help coral reefs survive moderate climate change. Ecol. Appl. 19: 3-17.

Bellwood D.R., Hughes T.P. 2001. Regional-scale assembly rules and biodiversity of coral reefs. Science 292: 1532-1535.

Berkelmans R., Van Oppen M.J.H. 2006. The role of zooxanthellae in the thermal tolerance of corals: a 'nugget of hope'for coral reefs in an era of climate change. Proc. R. Soc., B 273: 2305-2312.

Bruno J.F., Selig E.R. 2007. Regional decline of coral cover in the Indo-Pacific: timing, extent, and subregional comparisons. PLOS ONE. 2: e711.

Bryant D., Burke L., McManus J., Spalding M. 1998. Reefs at risk: a map-based indicator of threats to the world's coral reefs. World Resources Institute, Washington, DC.

Buddemeier R., Fautin D. 1993. Coral bleaching as an adaptive mechanism. BioScience 43: 320-326.

Burrows M.T., Schoeman D.S., Buckley L.B., Moore P., Poloczanska E.S., Brander K.M., Brown C., Bruno J.F., Duarte C.M., Halpern B.S. 2011. The Pace of Shifting Climate in Marine and Terrestrial Ecosystems. Science 334: 652-655.

Carpenter K.E., Abrar M., Aeby G., Aronson R.B., Banks S., Bruckner A., Chiriboga A., Cortes J., Delbeek J.C., Devantier L., Edgar G.J., Edwards A.J., Fenner D., Guzman H.M., Hoeksema B.W., Hodgson G., Johan O., Licuanan W.Y., Livingstone S.R., Lovell E.R., Moore J.A., Obura D.O., Ochavillo D., Polidoro B.A., Precht W.F., Quibilan M.C., Reboton C., Richards Z.T., Rogers A.D., Sanciangco J., Sheppard A., Sheppard C., Smith J., Stuart S., Turak E., Veron J.E., Wallace C., Weil E., Wood E. 2008. One-third of reef-building corals face elevated extinction risk from climate change and local impacts. Science 321: 560-563

Carroll L. 1871. Through the looking glass and what Alice found there. Arragon Publishing Inc (1913).

Coles S., Jokiel P., Lewis C. 1976. Thermal tolerance in tropical versus subtropical Pacific reef corals. Pac. Sci. 30: 159-166.

Coles S.L., Brown B.E. 2003. Coral bleaching-capacity for acclimatization and adaptation. Adv. Mar. Biol. 46: 183-223.

De' ath G., Lough J.M., Fabricius K.E. 2009. Declining coral calcification on the Great Barrier Reef. Science 323: 116-119.

Done T., Whetton P., Jones R., Berkelmans R., Lough J., Skirving W., Wooldridge S. 2003, Global Climate Change and Coral Bleaching on the Great Barrier Reef. In: Final Report to the State of Queensland Greenhouse Taskforce through the Department of Natural Resources and Minings, QDNRM, Brisbane. http://www.nrm.qld.gov.au/science/pdf/barrier_reef_report_1. pdf and http://www.nrm.qld.gov.au/science/pdff/barrier_reef_ report_2.pdf (Q. G. Department of Natural Resources, ed.).

Donner S.D. 2009. Coping with commitment: Projected thermal stress on coral reefs under different future scenarios. PLOS ONE 4: e5712.

Donner S.D., Skirving W.J., Little C.M., Oppenheimer M., HoeghGuldberg O. 2005. Global assessment of coral bleaching and required rates of adaptation under climate change. Global Change Biol. 11: 2251-2265.

Dove S. 2004. Scleractinian corals with photoprotective host pigments are hypersensitive to thermal bleaching. Mar. Ecol. Prog. Ser. 272: 99-116.

Fabricius K.E., Langdon C., Uthicke S., Humphrey C., Noonan S., De'ath G., Okazaki R., Muehllehner N., Glas M.S., Lough J.M. 2011. Losers and winners in coral reefs acclimatized to elevated carbon dioxide concentrations. Nat. Clim. Change 1: 165-169.

Gardner T.A., Côté I.M., Gill J.A., Grant A., Watkinson A.R. 2003. Long-term region-wide declines in Caribbean corals. Science 301: 958-960.

Greenstein B.J., Pandolfi J.M. 2008. Escaping the heat: range shifts 
of reef coral taxa in coastal Western Australia. Global Change Biol. 14: 513-528.

Halpern B.S., Walbridge S., Selkoe K.A., Kappel C.V., Micheli F., D’Agrosa C., Bruno J.F., Casey K.S., Ebert C., Fox H.E., Fujita R., Heinemann D., Lenihan H.S., Madin E.M.P., Perry M.T., Selig E.R., Spalding M., Steneck R., Watson R. 2008. A global map of human impact on marine ecosystems. Science 319: 948-952.

Hoegh-Guldberg O. 1999. Climate change, coral bleaching and the future of the world's coral reefs. Mar. Freshw. Res. 50: 839-866.

Hoegh-Guldberg O. 2009. Climate change and coral reefs: Trojan horse or false prophecy? Coral Reefs 28: 709-713.

Hoegh-Guldberg O., Salvat B. 1995. Periodic mass-bleaching and elevated sea temperatures - bleaching of outer reef slope communities in Moorea, French-Polynesia. Mar. Ecol. Prog. Ser. 121: $181-190$

Hoegh-Guldberg O., Mumby P.J., Hooten A.J., Steneck R.S., Greenfield P., Gomez E., Harvell C.D., Sale P.F., Edwards A.J., Caldeira K., Knowlton N., Eakin C.M., Iglesias-Prieto R., Muthiga N., Bradbury R.H., Dubi A., Hatziolos M.E. 2007. Coral reefs under rapid climate change and ocean acidification. Science 318: 1737-1742.

Hoegh-Guldberg O., Andréfouët S., Fabricius K., Diaz-Pulido G., Lough G., Marshall P., Pratchett M., 2011, Vulnerability of coral reefs in the tropical Pacific to climate change. In: Bell J., Johnson J., Hobday A. (eds.), Vulnerability of Tropical Pacific Fisheries and Aquaculture to Climate Change. Secretariat of the Pacific Community, Noumea, New Caledonia.

Hughes T.P. 1994. Catastrophes, phase shifts, and a large-scale degradation of a Caribbean coral Reef. Science 265: 1547-1551.

Hughes T.P., Rodrigues M.J., Bellwood D.R., Ceccarelli D., Hoegh-Guldberg O., McCook L., Moltschaniwskyj N., Pratchett M.S., Steneck R.S., Willis B. 2007. Phase shifts, herbivory, and the resilience of coral reefs to climate change. Curr. Biol. 17: 360-365.

Hughes T.P., Bellwood D., Baird A., Brodie J., Bruno J., Pandolfi J. 2011. Shifting base-lines, declining coral cover, and the erosion of reef resilience: comment on Sweatman et al. (2011). Coral Reefs 30: 653-660.

Hughes T.P., Baird A.H., Dinsdale E.A., Moltschaniwskyj N.A., Pratchett M.S., Tanner J.E., Willis B.L. 2012. Assembly rules of reef corals are flexible along a steep climatic gradient. Curr. Biol. 22: 736-741.

IPCC. 2007. Synthesis Report. Contribution of Working Groups I, II and III to the Fourth Assessment Report of the Intergovernmental Panel on Climate Change (C.W. Team, R.K. Pachauri, A. Reisinger, eds.). Intergovernmental Panel on Climate Change, Geneva, Switzerland, $104 \mathrm{pp}$

Kleypas J.A., Buddemeier R.W., Archer D., Gattuso J.P., Langdon C., Opdyke B.N. 1999a. Geochemical consequences of increased atmospheric carbon dioxide on coral reefs. Science 284: $118-20$

Kleypas J.A., McManus J.W., Menez L.A.B. 1999b. Environmental limits to coral reef development: Where do we draw the line? Amer. Zool. 39: 146-159.

LaJeunesse T.C. 2001. Investigating the biodiversity, ecology, and phylogeny of endosymbiotic dinoflagellates in the genus Symbiodinium using the its region: In search of a "species" level marker. J. Phycol. 37: 866-880.

Loya Y., Sakai K., Yamazato K., Nakano Y., Sambali H., van Woesik R. 2001. Coral bleaching: the winners and the losers. Ecol. Lett. 4: 122-131.

Marshall P.A., Baird A.H. 2000. Bleaching of corals on the Great Barrier Reef: differential susceptibilities among taxa. Coral Reefs 19: 155-163.

Maynard J., Anthony K., Marshall P., Masiri I. 2008. Major bleaching events can lead to increased thermal tolerance in corals. Mar. Biol. 155: 173-182.

McClanahan T.R., Obura D.O., Sheppard C.R.C. 2000. Coral reefs of the Indian Ocean: their ecology and conservation. Oxford University Press, New York, xxiii, $525 \mathrm{pp}$

McClanahan T., Maina J., Pet-Soede L. 2002. Effects of the 1998
Coral mortality event on Kenyan coral reefs and fisheries. Ambio 31: 543-550.

McClanahan T.R., Ateweberhan M., Graham N.A.J., Wilson S.K., Sebastian C.R., Guillaume M.M.M., Bruggemann J.H. 2007. Western Indian Ocean coral communities: bleaching responses and susceptibility to extinction. Mar. Ecol. Prog. Ser. 337: 1-13.

McClanahan T., Weil E., Cortés J., Baird A.H., Ateweberhan M. 2009. Consequences of coral bleaching for sessile reef organisms. In: Coral Bleaching: patterns, processes, causes and consequences. Ecological Studies, 205. Springer, Berlin, Germany, pp. 121-138.

McGehee M.A. 2008. Changes in the Coral Reef Community of Southwest Puerto Rico 1995 to 2005. Caribb. J. Sci. 44: 345-354.

Moberg F., Folke C. 1999. Ecological goods and services of coral reef ecosystems. Ecol. Econ. 29: 215-233.

Obura D.O. 2001. Kenya. Mar. Pollut. Bull. 42: 1264-1278.

Oliver T.A., Palumbi S.R. 2009. Distributions of stress-resistant coral symbionts match environmental patterns at local but not regional scales. Mar. Ecol. Prog. Ser. 387: 93-103.

Pandolfi J.M., Connolly S.R., Marshall D.J., Cohen A.L. 2011. Projecting coral reef futures under global warming and ocean acidification. Science 333: 418.

Parmesan C., Ryrholm N., Stefanescu C., Hill J.K., Thomas C.D. Descimon H., Huntley B., Kaila L., Kullberg J., Tammaru T. 1999. Poleward shifts in geographical ranges of butterfly species associated with regional warming. Nature 399: 579-583.

Parmesan C., Yohe G. 2003. A globally coherent fingerprint of climate change impacts across natural systems. Nature 421: 37-42.

Pelejero C., Calvo E., Hoegh-Guldberg O. 2010. Paleo-perspectives on ocean acidification. Trends Ecol. Evol. 25: 332-344.

Podestá G.P., Glynn P.W. 2001. The 1997-98 El Niño event in Panama and Galápagos: an update of thermal stress indices relative to coral bleaching. Bull. Mar. Sci. 69: 43-59.

Precht W.F., Aronson R.B. 2004. Climate flickers and range shifts of reef corals. Front. Ecol. Environ. 2: 307-314.

Rau G.H., McLeod E., Hoegh-Guldberg O. In press. The need for new conservation strategies and policies in a high $\mathrm{CO}_{2}$ world. Nat. Clim. Change.

Reaka-Kudla M.L. 1997. Global biodiversity of coral reefs: a comparison with rainforests. In: Reaka-Kudla M.L. and Wilson D.E. (eds.), Biodiversity II: Understanding and protecting our biological resources. Joseph Henry Press, $551 \mathrm{pp}$.

Riegl B. 2002. Effects of the 1996 and 1998 positive sea-surface temperature anomalies on corals, coral diseases and fish in the Arabian Gulf (Dubai, UAE). Mar. Biol. 140: 29-40.

Riegl B. 2003. Climate change and coral reefs: different effects in two high-latitude areas (Arabian Gulf, South Africa). Coral Reefs 22: 433-446.

Stat M., Carter D., Hoegh-Guldberg O. 2006. The evolutionary history of Symbiodinium and scleractinian hosts-symbiosis, diversity, and the effect of climate change. Persp. Plant Ecol. Evol. Syst. 8: 23-43.

Stockwell C.A., Hendry A.P., Kinnison M.T. 2003. Contemporary evolution meets conservation biology. Trends Ecol. Evol. 18: 94-101.

Sweatman H., Delean S., Syms C. 2011. Assessing loss of coral cover on Australia's Great Barrier Reef over two decades, with implications for longer-term trends. Coral Reefs 2: 521-531.

Van Valen L. 1973. A new evolutionary law. Evol. Theor. 1: 1-30.

West J.M., Salm R.V. 2003. Resistance and resilience to coral bleaching: implications for coral reef conservation and management. Conserv. Biol. 17: 956-967.

Yamano H., Sugihara K., Nomura K. 2011. Rapid poleward range expansion of tropical reef corals in response to rising sea surface temperatures. Geophysical Res. Lett. 38: L04601, doi:10.1029/2010GL046474.

Guest ed.: C. Pelejero.

Received August 21, 2011. Accepted May 3, 2012.

Published online June 8, 2012. 